\title{
Cholesteatoma - A Potential Consequence of Chronic Middle Ear Inflammation
}

\author{
Hagen Frickmann ${ }^{1,2}$ and Andreas Erich Zautner ${ }^{3 *}$
}

${ }^{1}$ Fachbereich Tropenmedizin am Bernhard-Nocht-Institut, Bundeswehrkrankenhaus Hamburg, Germany

${ }^{2}$ Institut für Medizinische Mikrobiologie, Virologie und Hygiene, Universitätsklinikum Rostock, Germany

${ }^{3}$ Abteilung für Medizinische Mikrobiologie, Universitätsmedizin Göttingen, Germany

\begin{abstract}
The article provides an overview on the current state-of-science of middle ear cholesteatoma, a non-neoplastic, keratinizing lesion that is characterized by the proliferation of epithelium with aberrant micro-architecture.

Pathogenetic mechanisms including morphological, immunological, epidemiological and microbiological aspects of the disease are summarized. The importance of penicillinase-expressing anaerobic bacteria and biofilm formation for maintaining the chronic middle ear inflammation is stressed. Nevertheless, the role of the isolated pathogens in the primarily non-sterile compartiment of the middle ear cavity is so far not completely understood and data on the isolated species are contradictious. Heredity was demonstated for some variants of the disease. Therefore, further studies on the etiological role of microbial agents and potential benefits of resistance-adapted antimicrobial therapy seem advisable.

Local and systemic complications of the potentially life-threatening disease like conductive and sensorineural hearing loss and cranial abscesses are reported. The prognosis is limited due to frequent recurrence in spite of surgical therapy. Further research is necessary for a better understanding of the pathogenetic mechanisms and to expand the sectrum of therapeutic options.
\end{abstract}

Keywords: Cholesteatoma; Biofilm; Chronic infection; Hyperproliferation; Complication

\section{Introduction}

Cholesteatoma is a non-neoplastic, keratinizing lesion [1], which is associated with enhanced proliferation of epithelial cells with aberrant morphologic characteristics [2]. Synonyms for cholesteatoma in the literature include epidermoid tumor, epidermoid cyst, and epithelial inclusion cyst [3]. Its first description is dated to the year 1683 [4].

While the middle ear is the most typical localization, ectopic cholesteatoma has been described for many sites, including the mastoid process [5], the petrous bone [6-8], the external auditory canal [9-14], the paranasal sinuses [15-17] with special emphasis on the frontal sinus [18-19], the genitourinary tract [20] including the ureter [21-23], the renal pelvis [21], the pyelocaliceal region [21], and the kidney [2426], as well as the endocranium, predominantly the cerebellopontine angle [27], and the posterior cerebellar fossa [28]. Cases of bi-lateral congenital middle ear cholesteatoma have been described [29-31], some of them in association with ossicular chain abnormalities [29,31], e.g. as an aspect of branchio-oto-renal syndrome [31].

Middle ear cholesteatoma forms a keratinic mass, consisting of matrix and perimatrix [32]. Some authors consider the pathogenic entity to be 'a serious form of chronic otitis media' [33]. Without therapy, it leads to progressive destruction of the middle and the inner ear [34]. It is subdivided into acquired and congenital cholesteatoma [1,35-37].

The acquired form is attributed to inflammatory otitic pathology and becomes rarer due to progresses in treatment [4]. Acquired cholesteatoma is typically associated with a defect of the tympanic membrane [1].

Congenital cholesteatoma is regularly a disease of infants, although this entity has been described in adults as well $[38,39]$. It usually grows behind an intact tympanic membrane [1]. Eustachian tube dysfunction is rare [40]. Typical features include satisfactory mastoid air cells and - in about one out of three cases - associated congenital malformations with or without involvement of the otologic system [41,42]. Despite agressive growth, in particular if functioning air cells in the mastoid are present, long latency periods without clinical symptoms have been described [42].

Cholesteatoma is particularly aggressive in childhood. Clinical diagnosis can be confirmed by modern imaging including CT and MR scans [4]. Rare differential diagnoses include the chorda tympani neuroma [43].

A favorable outcome depends to a large degree on an early diagnosis, but diagnosis is delayed in most instances. Thus, complications are frequent [44]

\section{Complications}

Although cholesteatoma is considered to be a benign process, spreading to surrounding structures may lead to severe, sometimes even life-threatening complications [19]. Most of the complications are infectious [4]. Advanced disease typically occurs in older children [45].

Typical acquired middle ear cholesteatoma, regularly associated

*Corresponding author: Andreas Erich Zautner, MD, Institut für Medizinische Mikrobiologie, Universitätsmedizin Göttingen, Kreuzbergring 57, D-37075 Göttingen, Germany, Tel: +49551/39-5758; Fax: +49551/39-5861; E-mail: azautne@gwdg.de

Received April 20, 2012; Accepted June 06, 2012; Published June 11, 2012

Citation: Frickmann H, Zautner AE (2012) Cholesteatoma - A Potentia Consequence of Chronic Middle Ear Inflammation. Otolaryngology S5:001. doi:10.4172/2161-119X.S5-001

Copyright: (c) 2012 Frickmann $\mathrm{H}$, et al. This is an open-access article distributed under the terms of the Creative Commons Attribution License, which permits unrestricted use, distribution, and reproduction in any medium, provided the original author and source are credited. 
with otitis media, may lead to temporal bone resorption, ossicular and otic capsule destruction, mastoid infiltration, tympanic membrane rupture, otorrhea, conductive hearing loss, sensorineural hearing loss, vestibular dysfunction, neuropathies, pain, and altered mental status [2,45-48].

Congenital cholesteatoma can present as acute mastoiditis with post-auricular pain or swelling [49]. Facial nerve paresis [13,50], lateral sinus thrombosis and cervical abscess (Bezold's abscess) due to partially recurrent cholesteatoma [51-53] have been reported. Even facial nerve transection due to cholesteatoma has been described [54]. Cholesteatomas of the petrous bone and the labyrinth were shown to be associated with cutaneous fistulas $[55,56]$.

Gradual intracranial involvement, e.g. into the posterior fossa, has been occassionally described $[3,48]$. Other endocranial complications include temporal lobe abscess, parietal lobe abscess, cerebellar abscess, extradural abscess, labyrinthine fistulas, invasion of the the labyrinth and fallopian canal, lateral sinus thrombophlebitis with subdural abscess, and meningitis [57-59] (Table 1).

At least infectious complications of cholesteatoma were reduced by the application of antibiotics [60].

\section{Pathogenesis}

Although keratinizing stratified squamous epithelium is well known as the pathological substrate of cholesteatoma [1], the understanding of the pathogenesis of cholesteatoma is still limited. Various animal models have been used so far in basic science to decipher the disease's pathophysiological processes [2]. In addition, immunohistochemistry of matrix and perimatrix contributed to the knowledge on pathogenesis of middle ear cholesteatoma [61].

\begin{tabular}{|l|l|}
\hline Site & Complication \\
\hline Systemic & Systemic infection \\
& Altered mental status \\
& Pain \\
\hline External ear & Otorrhea \\
\hline Middle ear & Temporal bone resorption \\
& Ossicular destruction \\
& Otic capsule destruction \\
& Tympanic membrane rupture \\
& Conductive hearing loss \\
\hline Inner ear & Sensorineural hearing loss \\
& Dysequilibrium due to vestibular dysfunction \\
\hline Periauricular & Local infection \\
Mastoid infiltration (e.g. acute mastoiditis) & Facial nerve paresis/transsection \\
& Cutaneous fistulas \\
& Cervical abscess (Bezold's abscess) \\
& Postauricular pain \\
& Postauricular swelling \\
\hline Intracranial & Invasion of posterior fossa \\
& Temporal lobe abscess \\
& Parietal lobe abscess \\
Cerebellar abscess \\
Extradural abscess \\
Invasion of the labyrinth and Fallopian canal \\
Lateral sinus thrombosis/thrombophlebitis \\
Subdural abscess \\
Meningitis \\
\hline
\end{tabular}

Table 1: Complications of middle ear cholesteatoma

\section{Origin and triggering factors}

Iatrogenic or non-iatrogenic tympanic membrane trauma like perforation, displacement, retraction or invagination, tympanic membrane disease, tympanic cavity mucosa disease, ear infection, and Eustachian tube dysfunction are likely to trigger acquired cholesteatoma developement $[1,48,62]$. Ectopic tissue immigration and retraction pockets are believed to be etiopathogenetically relevant, same as chronic inflammation [1]. Up to $10 \%$ of chronic otitis cases in children are associated with cholesteatoma [63] (Figure 1).

In contrast, congenital cholesteatoma might be explained by the postpartum persistence of a fetal epidermoid formation $[1,64,65]$, which physiologically persists at the junction of the Eustachian tube with the middle ear near the anterior limb of the tympanic ring until the 33rd gestation week [66] (Figure 1)

\section{Macroscopic findings}

In acquired middle ear cholesteatoma, tubal dysfunction leads to a retraction pocket according to the retraction pocket theory [61] The formation of retraction pockets is usually based on diseased mucosa [62] and facilitates the recruitment of initially planktonic bacteria due to a loss of defense mechanisms [67]. Within retraction pockets, cell debris and keratinocytes accumulate due to disturbed selfcleaning mechanisms as a consquence of local infection. However, this phenomenon is restricted to the rare cases of disturbed self-cleaning of keratinocytes, while normal migration of the squamous epithelium from the basal layers to the surface occurs in healthy individuals. Initially occuring 'micro-cholesteatomas' show confluence to the macroscopic cholesteatoma [61], which in turn leads to bone erosions [68] (Figure 1).

\section{Micro-morphological and immunological aspects}

Epithelium of cholesteatoma behaves more like 'wound-healing' than like neoplasm. There are no hints for inherent genetic instability [69]. Increased presence of fibronectin in cholesteatoma stroma has been observed [70]. Accumulating cell debris and keratinocytes of the cholesteatoma tissue are invaded by cells of the immune system including Langerhans' cells, T-cells, and macrophages [61]. The process is stimulated by an imbalance of epithelial proliferation, keratinocyte differentiation and maturation, as well as prolonged apoptosis [61]. Cell migration is replaced by hyperplasia under inflammatory conditions [62]. Hyperproliferation markers include Cytokeratin 16 (CK16), antigen Ki-67 and Proliferating Cell Nuclear Antigen (PCNA), which are overexpressed in the annulus tympanicus, adjacent meatus and tympanic regions [71]. The inflammation-driven epithelial proliferation is associated with an increased expression of lytic enzymes and cytokines including arachidonic acid, Intercellular Adhesion Molecule (ICAM), Receptor Activator Of Nuclear Factor Kappa-B Ligand (RANKL), Interleukin-1,-2 and -6 (IL-1, IL-2, IL6), Matrix Metalloproteinase-2 and -9 (MMP-2, MMP-9) as well as Tumor Necrosis Factor-alpha (TNF-alpha), which are partly induced by bacterial antigens $[61,68,72]$ including endotoxins like lipopolysaccharides [67]. Increased proliferative activity of epithelial cells is associated with increased nuclear content in the basal cells of colesteatoma as the morpholocial correlate of basal hyperplasia, being particularly pronounced in areas of inflammatory infiltration [73] Mast cells are present in high numbers in cholesteatoma tissue and may contribute to chronic inflammation [74]. Histamine and PlateletActivating Factor (PAF) lead to a disturbance of the Eustachian tube function, resulting in a disturbed mucociliary clearance. This 


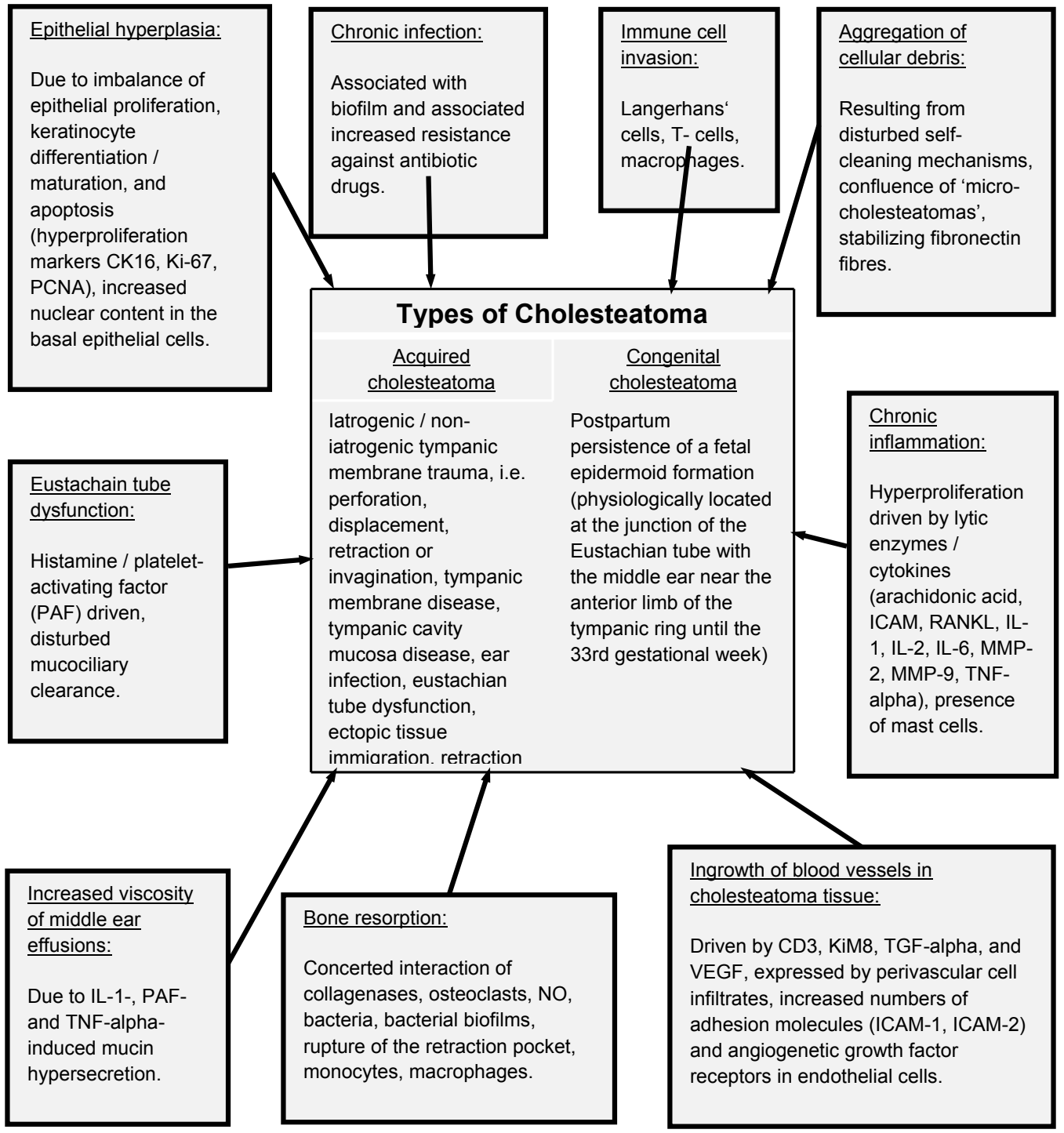

Figure 1: Pathogenesis of middle ear cholesteatoma.

process is aggravated by IL-1-, PAF- and TNF-alpha-induced mucin hypersecretion in the middle ear, leading to increased viscosity of middle ear effusions [61,75] (Figure 1).

The effector cells of released cytokines include osteoclasts, which lead to degradation of extracellular bone matrix and hyperproliferation, resulting in the macroscopically visible bone arrosion $[61,68,76-$ 78]. Other factors of importance for erosive bone depletion include collagenases, osteoclasts, nitric oxide (NO), bacteria including bacterial biofilms and rupture of the retraction pocket $[32,79]$. Large numbers of monocytes and macrophages accumulate in the contact area of cholesteatoma and bone, but only multi-nucleated osteoclasts are associated with disappearance of the bone surface [80] (Figure 1).

\section{Vascular aspects}

Hyperproliferative epithelial growth in cholesteatoma is supported by abundant blood vessels as a consequence of increased vascularization. Cholesteatoma stroma is characterized by numerous blood vessels with intact basal membrane, particularly in regions with abundant macrophage infiltration. Perivascular cellular infiltrates express angiogenetic factors like Cluster of Differentiation 3 (CD3), KiM8, Transforming Growth Factor-alpha (TGF-alpha), Vascular Endothelial Growth Factor (VEGF), and Human Histocompatibility Antigen (HLA-II) as a marker for cellular activation. Endothelial cells show Intercellular Adhesion Molecules (ICAM-1, ICAM-2) and angiogenetic growth factor receptors in increased numbers [81] (Figure 1)

\section{Microbiology}

As for many chronic infections, cholesteatoma was demonstrated to be associated with biofilm formation of infecting and/or colonizing bacteria [82-84]. In particular, avid biofilm-forming Pseudomonas aeruginosa strains have been isolated from cholesteatoma material [83]. Biofilms lead to impaired clearance, because bacteria within 
biofilm formations are well protected against host defense mechanisms as well as systemic or topical antibiotic drugs [75,85].

Next to Pseudomonas aeruginosa, Staphylococcus areus and anaerobic bacteria like Peptostreptococcus spp., Prevotella spp., Porphyromonas spp., Bacteroides spp. and Fusobacterium spp. are believed to be of etiological relevance for cholesteatoma development [86]. Gram-positive anaerobic cocci, Bacteroides spp., and Fusobacterium spp. were found in up to $50 \%$ of analyzed cholesteatoma tissues in a previous analysis. The expression of beta-lactamases in these anaerobic bacteria is common and should be considered if antibiotic therapy or peri-operative prophylaxis is intended [87].

In a previously published work, Pseudomonas aeruginosa was considered as the most relevant bacterial agent in pathology of cholesteatoma, followed by Staphylococcus aureus and Proteus mirabilis [88]. In contrast, we described a broad variety of aerobic and anaerobic Gram-positive and Gram-negative bacteria and even yeasts on ossicle samples that were overgrown by cholesteatoma in a recent study [89]. In detail, Acinetobacter baumannii, Aeromonas salmonicida, Bacillus licheniformis, Bacteroides urealyticus, Brevundimonas diminutiva, Burkholderia cenocepacia, Candida albicans, Clostridium bifermentans, Corynebacterium pseudodiphtheriticum, Eubacterium limosum, Haemophilus somnus, Kocuria rosea, Leuconostoc mesenteroides spp. cremoris, Micrococcus luteus, Neisseria sicca, Neisseria subflava, Propionibacterium acnes, Propionibacterium granulosum, Pseudomonas aeruginosa, Pseudomonas fluorescence, Ralstonia pickettii, Sphingomonas paucimobilis, Staphylococcus aureus, Staphylococcus auricularis, Staphylococcus capitis, Staphylococcus epidermidis, Staphylococcus hominis, Staphylococcus simulans, Streptococcus mitis, Streptococcus sanguinis, Turicella otidis, and Veilonella parvula were isolated. Only half of the tested bacteria showed in-vitro single species biofilm formation [89]. However, discrimination of infecting pathogens and harmless colonizers in primarily non-sterile compartments like middle ear is hardly possible. The mentioned species comprise facultative pathogens or typical commensals (Table 2).

\section{Hereditiy}

A single Danish paper provides hints on potential hereditary factors that might interact with other factors in the onset of acquired cholesteatoma. A family from Greenland with an unusual accumulation of chlolesteatoma patients was described [90].

\section{Imaging}

Computed Tomography (CT) and Magnetic Resonance (MR) cross-sectional scans are used for pre-operative assessment and post-operative follow-up [4,91-96]. These techniques replaced the formerly common plain petro-mastoid views, from which the lateral with caudal tilt of the tube was considered to be the most useful as it demonstrates the extent of pneumatisation and the position of the lateral sinus and middle fossa dura [97]. The drawback of CT scanning is its low specificity, i.e. its failure to discriminate soft-tissue structures [98]. Precise diagnosis is usually based on gadolinium-enhanced T1-weighted and diffusion-weighted MRI sequences [4]. Diffusion weighted MR imaging is advicable if CT scans lead to equivocal results [99].

Further, diffusion-weighted magnetic resonance imaging scans are the method of choice to detect residual or recurrent middle ear cholesteatoma after surgery [100]. The differentiation from granulation tissue, inflammatory tissue, or fluid within the middle ear cavity and mastoid cavity is challenging [101]. Non-echo-planar imaging, e.g. half Fourier acquisition single-shot turbo spin echo sequences, yield the most reliable results for this indication [100] and outperforms traditional approaches like high-resolution computed tomography, conventional magnetic resonance imaging, and delayed contrast magnetic resonance imaging [101].

Rarely used imaging approaches include optical coherence tomography, allowing for non-invasive imaging with micrometer resolution and therefore being well-suited for the diagnosis of middle ear cholesteatoma [102].

\section{Therapy}

Surgery is the treatment of choice for cholesteatoma [103106]. Surgical approaches should aim to avoid residual or recurrent cholesteatoma. A good functional result, including improvement of hearing, is of secondary importance $[107,108]$. The third aim is the restoration of ear anatomy [109]. Treatment approaches by laser showed less promising results [4]. Single-stage procedures are favored for the reconstruction of the sound conduction system [108]. The outcome is highly depending on the extent of the cholesteatoma-induced lesion [110]. Individualized approaches, taking anatomic, clinical and social factors into account, are necessary to yield optimal results, in particular in young infants $[37,111,112]$. The likelihood of compliance should be considered for the design of the management plan, because adherence may be a relevant problem, particularly in children [113].

Typical approaches in surgery of cholesteatoma of the mastoid include preservation or reconstruction of the posterior meatal wall with an aerated mastoid, partial or complete obliteration of the mastoid after removal of the posterior wall, and leaving the cavity open for inspection [108]. Canal wall-preserving techniques are common [101]. Cavity obliteration is important to protect vital neurovascular structures, which can be exposed during operation [50].

Though the use of autogenous ossicles leads to the best results concerning the reconstruction of the sound conducting system in cholesteatoma surgery, ingrowth of matrix epithelia often limits

\begin{tabular}{|l|l|}
\hline Group & Isolated agents \\
\hline $\begin{array}{l}\text { Gram-negative } \\
\text { aerobic bacteria }\end{array}$ & $\begin{array}{l}\text { Aeromonas salmonicida, Acinetobacter baumannii, Burkholderia cenocepacia, Brevundimonas diminutiva, Haemophilus somnus, Neisseria } \\
\text { sicca, Neisseria subflava, Pseudomonas aeruginosa, Pseudomonas fluorescence, Ralstonia pickettii, Sphingomonas paucimobilis, }\end{array}$ \\
\hline $\begin{array}{l}\text { Gram-positive aerobic } \\
\text { bacteria }\end{array}$ & $\begin{array}{l}\text { Bacillus licheniformis, Corynebacterium pseudodiphtheriticum, Kocuria rosea, Leuconostoc mesenteroides spp. cremoris, Micrococcus } \\
\text { luteus, Staphylococcus aureus, Staphylococcus auricularis, Staphylococcus capitis, Staphylococcus epidermidis, Staphylococcus hominis, } \\
\text { Staphylococcus simulans, Streptococcus mitis, Streptococcus sanguinis, Turicella otidis }\end{array}$ \\
\hline $\begin{array}{l}\text { Gram-negative } \\
\text { anaerobic bacteria }\end{array}$ & Bacteroides urealyticus, Eubacterium limosum, Porphyromonas spp., Prevotella spp., Veilonella parvula \\
\hline $\begin{array}{l}\text { Gram-positive } \\
\text { anaerobic bacteria }\end{array}$ & Clostridium bifermentans, Fusobacterium spp., Peptostreptococcus spp., Propionibacterium acnes, Propionibacterium granulosum \\
\hline Yeasts & Candida albicans \\
\hline
\end{tabular}

Table 2: Infectious microorganisms isolated from cholesteatoma material or ossicles that were overgrown by cholesteatoma [83,86,89]. 
their use. High-hydrostatic pressure treatment was shown to reliably inactivate epithelial cells prior to a replantation of ossicles [114]. However, as previously shown by our group, high-hydrostatic pressure fails to completely inactivate bacteria on these ossicles. The effect is particularly reduced for biofilm formers, so only a reduction of bacterial count can be achieved [89]. The question, whether such reductions of bacterial counts may nevertheless contribute to a more favorable clinial outcome, has still to be answered in further studies.

\section{Prognosis}

Despite surgical interventions, risk of recurrence of cholesteatoma is high. Postoperative complications and recurrence are more common in acquired than in congenital cholesteatoma, with early detection being the most important predictor for a favorable outcome [40,115,116]. Recurrence rates of $<10 \%$ should be aimed [117]. Iatrogenic cholesteatoma of the neck has been described as a late complication of radical mastoidectomy to cure a cholesteatoma [118].

Postoperative follow-up is advisable in order not to miss infections, stenosis, and recurrence of cholesteatoma [13]. Second-look surgery is mandatory to exclude residual or recurrent disease, because clinical and otoscopic diagnosis is not reliable for this indication [101]. Life-long follow-up is necessary due to a high incidence of delayed recurrence [3]. Recurrence is more frequent in infants than in adults [109]. Proven risk factors of recurrence of the disease after surgical intervention include posterior mesotympanum involvement, ossicular chain interruption after disease excision, relative lack of experience of the surgeon, and presumed incomplete removal [119] (Table 3).

\section{Prophylaxis}

Due to the important role of chronic inflammation in acquired cholesteatoma, early treatment of inflammatory conditions has prophylactic effects, e.g. by preventing the development of hyperplastic papillary protrusions [1].

\section{Discussion}

Though the understanding of middle ear cholesteatoma pathogenesis advances, prognosis is limited by frequent recurrence of disease despite surgical intervention $[40,116]$. Inflammation due to chronic otitis is the only risk factor for the development of cholesteatoma that can be relevantly influenced $[1,60,63]$.

However, microbiology of cholesteatoma is poorly understood. Even data regarding the causative infectious agents are contradictory [86-89], making anti-infectious therapy challenging. Anaerobic bacteria are frequently isolated $[86,87]$ and should be considered.

Though biofilm forming bacteria were described to be of importance for the pathogenesis of cholesteatoma, we could demonstrate in-vitro biofilm formation in no more than a half of the isolates from ossicles that were overgrown by cholesteatoma [89]. Hypertrophic infected tonsils are a crucial factor to a reduced clearance of infectious detritus from the middle ear cavity by blocking the Eustachian tube [120]. Intra-cellular persistence of bacteria was demonstrated by our group

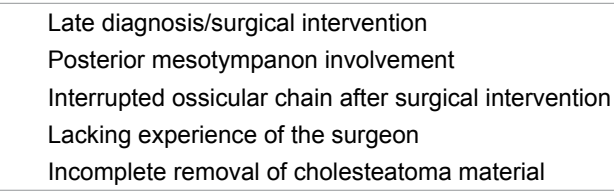

Table 3: Unfavorable prognostic factors. to be of patho-etiological relevance for recurrent adentotonsillar disease $[120,121]$. These pathogens persisting intra-cellularly in the adenotonsills might ascent from this spatially related reservoir through the Eustachian tube to the middle ear and may lead to recurrent otitis media [121]. However, a direct role of intra-cellularly persistent bacteria in cholesteatoma tissue was not examined so far.

Although antibiotic therapy of chronic otitis media is generally accepted [122], acquired cholesteatoma is common, demanding futher optimization. Therefore, further studies to unveil the exact role of infection in the pathogenesis of cholesteatoma are required, same as further research on the standardization of antibiotic therapy. A better control of chronic otitis media might lead to an additional decrease in the incidence of acquired cholesteatoma.

\section{Acknowledgments}

This publication was funded by the Open Access support program of the Deutsche Forschungsgemeinschaft and the publication fund of the Georg August Universität of Göttingen.

\section{References}

1. Persaud R, Hajioff D, Trinidade A, Khemani S, Bhattacharyya MN, et al. (2007) Evidence-based review of aetiopathogenic theories of congenital and acquired cholesteatoma. J Laryngol Otol 121: 1013-1019.

2. Yamamoto-Fukuda T, Takahashi H, Koji T (2011) Animal models of middle ear cholesteatoma. J Biomed Biotechnol 2011: 394241.

3. Habesoglu TE, Balak N, Habesoglu M, Zemheri E, Isik N, et al. (2009) Intracranial cholesteatoma - case report and critical review. Clin Neuropathol 28: $440-444$

4. Nevoux J, Lenoir M, Roger G, Denoyelle F, Ducou Le Pointe H, et al. (2010) Childhood cholesteatoma. Eur Ann Otorhinolaryngol Head Neck Dis 127: 143150 .

5. Giannuzzi AL, Merkus P, Taibah A, Falcioni M (2011) Congenital mastoid cholesteatoma: case series, definition, surgical key points, and literature review. Ann Otol Rhinol Laryngol 120: 700-706.

6. Glasscock ME 3rd, Woods Cl 3rd, Poe DS, Patterson AK, Welling DB (1989) Petrous apex cholesteatoma. Otolaryngol Clin North Am 22: 981-1002.

7. Kikuchi S, Yamasoba T, Harada T, Kitamura K, Sasaki T (1993) Congenital cholesteatoma of the petrous pyramid. ORL J Otorhinolaryngol Relat Spec 55 236-239.

8. Yamazaki K, Sato H, Murai K, Ogawa K (2005) Infantile congenital petrosa cholesteatoma: a case report and literature review. Int J Pediatr Otorhinolaryngol 69: 1703-1707.

9. Farrior J (1990) Cholesteatoma of the external ear canal. Am J Otol 11: 113 116.

10. Fernández Pérez A, Fernández-Nogueras Jiménez F, Moreno León J (1998) Cholesteatoma of the external ear canal. A case report. Acta Otorrinolaringol Esp 49: 60-62

11. Persaud RA, Hajioff D, Thevasagayam MS, Wareing MJ, Wright A (2004) Keratosis obturans and external ear canal cholesteatoma: how and why we should distinguish between these conditions. Clin Otolaryngol Allied Sci 29: 577-581.

12. Verdaguer JM, Trinidad A, Lobo D, García-Berrocal JR, Ramírez-Camacho R (2006) External auditory canal cholesteatoma as a complication of ear surgery. Acta Otorrinolaringol Esp 57: 378-380.

13. Belcadhi M, Chahed H, Mani R, Bouzouita K (2010) Therapeutic approaches to complicated cholesteatoma of the external auditory canal: a case of associated facial paresis. Ear Nose Throat J 89: E1-E6

14. Mazita A, Zabri M, Aneeza WH, Asma A, Saim L (2011) Cholesteatoma in patients with congenital external auditory canal anomalies: retrospective review. J Laryngol Otol 125: 1116-1120.

15. Cobarro J, Valles H, Blanch JL, Alos L, Traserra J (1991) Cholesteatoma of the paranasal sinuses. Apropos of 2 cases. Ann Otolaryngol Chir Cervicofac 108: $307-310$. 
Citation: Frickmann H, Zautner AE (2012) Cholesteatoma - A Potential Consequence of Chronic Middle Ear Inflammation. Otolaryngology S5:001. doi:10.4172/2161-119X.S5-001

16. Hartman JM, Stankiewicz JA (1991) Cholesteatoma of the paranasal sinuses: case report \& review of the literature. Ear Nose Throat J 70: 719-725.

17. Storper IS, Newman AN (1992) Cholesteatoma of the maxillary sinus. Arch Otolaryngol Head Neck Surg 118: 975-977.

18. Hansen S, Sørensen CH, Stage J, Mouritzen A, Cayé-Thomasen P (2007) Massive cholesteatoma of the frontal sinus: case report and review of the literature. Auris Nasus Larynx 34: 387-392.

19. Hammami B, Mnejja M, Chakroun A, Achour I, Chakroun A, et al. (2010) Cholesteatoma of the frontal sinus. Eur Ann Otorhinolaryngol Head Neck Dis 127: 213-216.

20. Ganeshappa A, Krambeck A, Grignon DJ, Lingeman JE (2009) Endoscopic management of keratinizing desquamative squamous metaplasia of the upper tract: a case report and review of the literature. J Endourol 23: 1277-1279.

21. Pastor Guzmán JM, Hernández Millán I, Salinas Sánchez AS, Martínez Martín $M$, Cañamares Pabolaza L, et al. (1994) Keratinizing squamous metaplasia (cholesteatoma) of the upper urinary tract. Actas Urol Esp 18: 811-815.

22. Sugamoto T, Yokoyama M, Nishio S, Takeuchi M (1997) Cholesteatoma of the ureter: a case report. Int J Urol 4: 621-622.

23. Tamura Y, Yumura Y, Senga Y, Goto A, Sakuramoto T (2005) A case report of cholesteatoma of the ureter difficult to distinguish from malignant ureter tumor. Hinyokika Kiyo 51: 331-333.

24. González Castillo $P$, Mora MJ, Mañas A, Extramiana J, Manzarbeitia $F$, et al. (1992) Renal cholesteatoma: keratin accumulation tumor. Actas Urol Esp; 16: 39-43.

25. Gruenwald I, Lurie A (1994) Cholesteatoma of the kidney--update. Harefuah 126: 35-37.

26. König J, Pannek J, Kickuth R, Noldus J (2004) Late recurrence of renal cholesteatoma after 15 years. Urology 64: 808-809.

27. Moffat DA, Quaranta N, Baguley DM, Hardy DG, Chang P (2002) Staging and management of primary cerebellopontine cholesteatoma. J Laryngol Otol 116 340-345.

28. Jeanbourquin D, Cordoliani YS, Derosier C, Cosnard G (1993) Cholesteatoma of the posterior cerebral fossa. 7 cases and review of the literature. J Radiol 74: $555-561$.

29. Suetake M, Kobayashi T, Takasaka T (1991) Bilateral congenita cholesteatomas associated with ossicular anomalies: a case report. Am J Otol 12: $132-134$

30. Litman RS, Smouha E, Sher WH, Shangold LM (1996) Two cases of bilatera congenital cholesteatoma--usual and unusual presentations. Int J Pediatr Otorhinolaryngol 36: 241-252.

31. Worley GA, Vats A, Harcourt J, Albert DM (1999) Bilateral congenital cholesteatoma in branchio-oto-renal syndrome. J Laryngol Otol 113: 841-843.

32. Gersdorff MC, Debaty ME, Tomasi JP (2006) Pathophysiology of cholesteatoma Rev Laryngol Otol Rhinol (Bord) 127: 115-119.

33. Ayache D, Schmerber S, Lavieille JP, Roger G, Gratacap B (2006) Middle ear cholesteatoma. Ann Otolaryngol Chir Cervicofac 123: 120-137.

34. McKennan KX (1991) Cholesteatoma: recognition and management. Am Fam Physician 43: 2091-2096.

35. Sie KC (1996) Cholesteatoma in children. Pediatr Clin North Am 43: 1245 1252.

36. Lesinskas E, Kasinskas R, Vainutiene V (2002) Middle ear cholesteatoma: present-day concepts of etiology and pathogenesis. Medicina (Kaunas) 38 : 1066-1071.

37. Shohet JA, de Jong AL (2002) The management of pediatric cholesteatoma Otolaryngol Clin North Am 35: 841-851.

38. Suetake M, Kobayashi T, Sasaki N, Takasaka T, Yuasa R (1996) Congenita cholesteatomas in Japanese--forty from our experience and fifty-five from a survey of the Japanese literature. Nihon Jibiinkoka Gakkai Kaiho 99: 12001207

39. Mornet E, Martins-Carvalho C, Valette G, Potard G, Marianowski R (2008) Adult localized congenital cholesteatoma. Ann Otolaryngol Chir Cervicofac 125: 85-89.
40. Bennett M, Warren F, Jackson GC, Kaylie D (2006) Congenital cholesteatoma: theories, facts, and 53 patients. Otolaryngol Clin North Am 39: 1081-1094

41. el Jerrari A, Stierle JL, Debry C, Veillon F, Gentine A, et al. (1995) Congenital cholesteatoma and associated ossicular malformations. Ann Otolaryngol Chir Cervicofac 112: 258-261.

42. Duclos JY, Darrouzet V, Portmann D, Portmann M, Bébéar JP (1999) Congenital cholesteatoma of the ear in the child. Clinical, follow-up and therapeutic analysis of a series of 34 cases. Ann Otolaryngol Chir Cervicofac 116: 218-227.

43. Hopkins C, Chau H, McGilligan JA (2003) Chorda tympani neuroma masquerading as cholesteatoma. J Laryngol Otol 117: 987-988.

44. Chang P, Kim S (2008) Cholesteatoma--diagnosing the unsafe ear. Aust Fam Physician 37: 631-638.

45. Richter GT, Lee KH (2009) Contemporary assessment and management of congenital cholesteatoma. Curr Opin Otolaryngol Head Neck Surg 17: 339-435.

46. Olszewska E, Wagner M, Bernal-Sprekelsen M, Ebmeyer J, Dazert S, et al (2004) Etiopathogenesis of cholesteatoma. Eur Arch Otorhinolaryngol 261 $6-24$.

47. Rash EM (2004) Recognize cholesteatomas early. Nurse Pract 29: 24-27.

48. McHugh TP (2007) Intracranial cholesteatoma: a case report and review. J Emerg Med 32: 375-379.

49. Hidaka H, Ishida E, Kaku K, Nishikawa H, Kobayashi T (2010) Congenital cholesteatoma of mastoid region manifesting as acute mastoiditis: case report and literature review. J Laryngol Otol 124: 810-815.

50. Sanna M, Pandya Y, Mancini F, Sequino G, Piccirillo E (2011) Petrous bone cholesteatoma: classification, management and review of the literature. Audio Neurootol 16: 124-136.

51. Lubianca Neto JF, Saffer M, Rotta FT, Arrarte JL, Brinckmann CA, et al. (1998) Lateral sinus thrombosis and cervical abscess complicating cholesteatoma in children: case report and review. Int J Pediatr Otorhinolaryngol 42: 263-269.

52. Uchida Y, Ueda H, Nakashima T (2002) Bezold's abscess arising with recurrent cholesteatoma 20 years after the first surgery: with a review of the 18 cases published in Japan since 1960. Auris Nasus Larynx 29: 375-378.

53. García González LA, López Aguado D (2005) Lateral sinus thrombosis due to cholesteatoma. Report of a case and literature review. An Otorrinolaringo Ibero Am 32: 527-536.

54. Waddell A, Maw AR (2001) Cholesteatoma causing facial nerve transection. J Laryngol Otol 115: 214-215.

55. Portier F, Lescanne E, Racy E, Nowak C, Lamblin B, et al. (2005) Studies of labyrinthine cholesteatoma-related fistulas: report of 22 cases. J Otolaryngol 34: 1-6.

56. Lin Y, Chen Y, Lu LJ, Qiao L, Qiu JH (2009) Primary cholesteatoma of petrous bone presenting as cervical fistula. Auris Nasus Larynx 36: 466-469.

57. Bartels LJ (1991) Facial nerve and medially invasive petrous bone cholesteatomas. Ann Otol Rhinol Laryngol 100: 308-316.

58. Vanden Abeele D, Offeciers FE (1993) Management of labyrinthine fistulas in cholesteatoma. Acta Otorhinolaryngol Belg; 47: 311-321.

59. Darrouzet V, Duclos JY, Portmann D, Portmann M, Bebear JP (1997) Cholesteatoma of the middle ear in children. Clinical, developing and therapeutic study in a series of 215 consecutive cases. Ann Otolaryngol Chir Cervicofac 114: 272-283.

60. Smith JA, Danner CJ (2006) Complications of chronic otitis media and cholesteatoma. Otolaryngol Clin North Am 39: 1237-1255.

61. Welkoborsky HJ (2011) Current concepts of the pathogenesis of acquired middle ear cholesteatoma. Laryngorhinootologie 90: 38-48.

62. Louw L (2010) Acquired cholesteatoma pathogenesis: stepwise explanations J Laryngol Otol 124: 587-593.

63. Triglia JM, Gillot JC, Giovanni A, Cannoni M (1993) Cholesteatoma of the middle ear in children. Apropos of 80 cases and review of the literature. Ann Otolaryngol Chir Cervicofac 110: 437-443.

64. Karmody CS, Byahatti SV, Blevins N, Valtonen H, Northrop C (1998) The origin of congenital cholesteatoma. Am J Otol 19: 292-297. 
Citation: Frickmann H, Zautner AE (2012) Cholesteatoma - A Potential Consequence of Chronic Middle Ear Inflammation. Otolaryngology S5:001. doi:10.4172/2161-119X.S5-001

Page 7 of 8

65. Sudhoff H, Liang J, Dazert S, Borkowski G, Michaels L (1999) Epidermoid formation in the pathogenesis of congenital cholesteatoma--a current review. Laryngorhinootologie 78: 63-67.

66. Michaels $L$ (1988) Origin of congenital cholesteatoma from a normally occurring epidermoid rest in the developing middle ear. Int J Pediatr Otorhinolaryngol 15 $51-65$

67. Olszewska E, Chodynicki S (2004) Immunological problems in middle ear cholesteatoma. Otolaryngol Pol 58: 85-90.

68. Vitale RF, Pereira CS, Alves AL, Fregnani JH, Ribeiro FQ (2011) TNF-R2 expression in acquired middle ear cholesteatoma. Braz J Otorhinolaryngol 77 531-536.

69. Albino AP, Kimmelman CP, Parisier SC (1998) Cholesteatoma: a molecular and cellular puzzle. Am J Otol 19: 7-19.

70. Schilling V, Holly A, Bujía J, Schulz P, Kastenbauer E (1995) High levels of fibronectin in the stroma of aural cholesteatoma. Am J Otolaryngol 16: 232-235.

71. Caliman e Gurgel JD, Pereira SB, Alves AL, Ribeiro FQ (2010) Hyperproliferation markers in ear canal epidermis. Braz J Otorhinolaryngol 76: 667-671.

72. Milewski C (1998) Role of perimatrix fibroblasts in development of acquired middle ear cholesteatoma. A hypothesis. HNO 46: 494-501.

73. Amador JM, Esquivias JJ, Ciges M (1994) The study of proliferative epithelial activity in cholesteatoma of the middle ear during cytomorphophotometry. Acta Otorrinolaringol Esp 45: 71-78.

74. Albino AP, Reed JA, Bogdany JK, Sassoon J, Parisier SC (1998) Increased numbers of mast cells in human middle ear cholesteatomas: implications for treatment. Am J Otol 19: 266-272.

75. Juhn SK, Jung MK, Hoffman MD, Drew BR, Preciado DA, et al. (2008) The role of inflammatory mediators in the pathogenesis of otitis media and sequelae. Clin Exp Otorhinolaryngol 1: 117-138.

76. Bujía J (1994) New immunobiologic trends concerning etiopathogenicity of cholesteatoma. An Otorrinolaringol Ibero Am 21: 199-206.

77. Semaan MT, Megerian CA (2006) The pathophysiology of cholesteatoma. Otolaryngol Clin North Am 39: 1143-1159.

78. Vitale RF, Ribeiro Fde A (2007) The role of tumor necrosis factor-alpha (TNF-alpha) in bone resorption present in middle ear cholesteatoma. Braz $J$ Otorhinolaryngol 73: 117-121.

79. Dornelles C, Costa SS, Meurer L, Schweiger C (2005) Some considerations about acquired adult and pediatric cholesteatomas. Braz J Otorhinolaryngol 71: 536-545

80. Chole RA (1984) Cellular and subcellular events of bone resorption in human and experimental cholesteatoma: the role of osteoclasts. Laryngoscope 94: 7695.

81. Bujía J, Holly A, Stammberger M, Sudhoff H (1996) Angiogenesis in cholesteatoma of the middle ear. Acta Otorrinolaringol Esp 47: 187-192.

82. Post JC, Stoodley P, Hall-Stoodley L, Ehrlich GD (2004) The role of biofilms in otolaryngologic infections. Curr Opin Otolaryngol Head Neck Surg 12: 185-190.

83. Post JC, Hiller NL, Nistico L, Stoodley P, Ehrlich GD (2007) The role of biofilms in otolaryngologic infections: update 2007. Curr Opin Otolaryngol Head Neck Surg 15: 347-351.

84. Macassey E, Dawes $P$ (2008) Biofilms and their role in otorhinolaryngological disease. J Laryngol Otol 122: 1273-1278.

85. Chole RA, Faddis BT (2002) Evidence for microbial biofilms in cholesteatomas. Arch Otolaryngol Head Neck Surg 128: 1129-1133.

86. Brook I (1995) Role of anaerobic bacteria in chronic otitis media and cholesteatoma. Int J Pediatr Otorhinolaryngol 31: 153-157.

87. Brook I (1987) The role of anaerobic bacteria in otitis media: microbiology, pathogenesis, and implications on therapy. Am J Otolaryngol 8: 109-117.

88. Ricciardiello F, Cavaliere M, Mesolella M, Lengo M (2009) Notes on the microbiology of cholesteatoma: clinical findings and treatment. Acta Otorhinolaryngol Ital 29: 197-202.

89. Dommerich S, Frickmann H, Ostwald J, Lindner T, Zautner AE, et al. (2012) Effects of high hydrostatic pressure on bacterial growth on human ossicles explanted from cholesteatoma patients. PLoS ONE 7: e30150.
90. Homøe P, Rosborg J (2007) Family cluster of cholesteatoma. J Laryngol Oto 121: 65-67.

91. Liu DP, Bergeron RT (1989) Contemporary radiologic imaging in the evaluation of middle ear-attic-antral complex cholesteatomas. Otolaryngol Clin North Am 22: 897-909.

92. Mafee MF, Kumar A, Heffner DK (1994) Epidermoid cyst (cholesteatoma) and cholesterol granuloma of the temporal bone and epidermoid cysts affecting the brain. Neuroimaging Clin N Am 4: 561-578.

93. Pisaneschi MJ, Langer B (2000) Congenital cholesteatoma and cholestero granuloma of the temporal bone: role of magnetic resonance imaging. Top Magn Reson Imaging 11: 87-97.

94. Watts S, Flood LM, Clifford K (2000) A systematic approach to interpretation of computed tomography scans prior to surgery of middle ear cholesteatoma. $J$ Laryngol Otol 114: 248-253.

95. Williams MT, Ayache D (2004) Imaging of the postoperative middle ear. Eu Radiol 14: 482-495.

96. Vercruysse JP, De Foer B, Somers T, Casselman J, Offeciers E (2009) Magnetic resonance imaging of cholesteatoma: an update. B-ENT 5: 233-240.

97. Phelps PD, Lloyd GA (1980) The radiology of cholesteatoma. Clin Radiol 31 501-512.

98. Baráth K, Huber AM, Stämpfli P, Varga Z, Kollias S (2011) Neuroradiology of cholesteatomas. AJNR Am J Neuroradiol 32: 221-229.

99. Schwartz KM, Lane JI, Bolster BD Jr, Neff BA (2011) The utility of diffusionweighted imaging for cholesteatoma evaluation. AJNR Am J Neuroradiol 32 430-436.

100. Jindal M, Riskalla A, Jiang D, Connor S, O'Connor AF (2011) A systematic review of diffusion-weighted magnetic resonance imaging in the assessment of postoperative cholesteatoma. Otol Neurotol 32: 1243-1249.

101. Khemani S, Singh A, Lingam RK, Kalan A (2011) Imaging of postoperative middle ear cholesteatoma. Clin Radiol 66: 760-767.

102. Ovári A, Pau HW, Just $T$ (2011) Optical coherence tomography in otolaryngology. Orv Hetil 152: 1125-1132.

103. Black B (1991) Cholesteatomatous otitis media. Aust Fam Physician 20: 806 808.

104. Darrouzet V, Dutkievicz J, Chambrin A, Diab S, Dautheribes M, et al. (1997) Endocranial complications of cholesteatoma: apropos of 8 cases. Rev Laryngol Otol Rhinol (Bord) 118: 79-86.

105. Charachon R, Schmerber S, Lavieille JP (1999) Middle ear cholesteatoma surgery. Ann Otolaryngol Chir Cervicofac 116: 322-340.

106. Palva T, Ramsay H (1999) Chronic inflammatory ear disease and cholesteatoma: creation of auxiliary attic aeration pathways by microdissection. Am J Otol 20: 145-151.

107. Caprio D, Strunski V, Batteur B, Marzuoli L, Porta P, et al. (1995) Audiometric results of 81 ossiculoplasties after tympanoplasty with closed technique in chronic cholesteatomatous otitis. Ann Otolaryngol Chir Cervicofac 112: 107117.

08. Stark T, Gurr A, Sudhoff H (2011) Principles of cholesteatoma surgery. HNO 59: 393-399.

109. De la Cruz A, Fayad JN (1999) Detection and management of childhood cholesteatoma. Pediatr Ann 28: 370-373.

110. Isaacson G (2007) Diagnosis of pediatric cholesteatoma. Pediatrics 120: 603608.

111. Karmarkar S, Bhatia S, Saleh E, DeDonato G, Taibah A, et al. (1995) Cholesteatoma surgery: the individualized technique. Ann Otol Rhino Laryngol 104: 591-595.

112. Schraff SA, Strasnick B (2006) Pediatric cholesteatoma: a retrospective review. Int J Pediatr Otorhinolaryngol 70: 385-393.

113. Arriaga MA (1994) Cholesteatoma in children. Otolaryngol Clin North Am 27 : 573-591.

114. Dommerich S, Pau HW, Lindner T, Just T, Ostwald J (2010) Devitalization of cholesteatoma on human cssicles by hydrostatic high pressure treatment. Laryngorhinootologie 89: 284-288. 
Citation: Frickmann H, Zautner AE (2012) Cholesteatoma - A Potential Consequence of Chronic Middle Ear Inflammation. Otolaryngology S5:001. doi:10.4172/2161-119X.S5-001

Page 8 of 8

115. Zini C, Bacciu S, Pasanisi E, Bortesi G (1991) Pathogenesis and prevention of recurrent cholesteatoma following closed tympanoplasty. Acta Otorhinolaryngol Belg 45: 43-49.

116. Kazahaya K, Potsic WP (2004) Congenital cholesteatoma. Curr Opin Otolaryngol Head Neck Surg 12: 398-403.

117. Palva T (1990) The pathogenesis and treatment of cholesteatoma. Acta Otolaryngol 109: 323-330.

118. Fliss DM, Puterman M, Tovi F (1989) latrogenic cholesteatoma of the neck. Head Neck 11: 558-561.
119. Roger G, Denoyelle F, Chauvin P, Schlegel-Stuhl N, Garabedian EN (1997) Predictive risk factors of residual cholesteatoma in children: a study of 256 cases. Am J Otol 18: 550-558.

120.Zautner AE (2012) Adenotonsillar disease. Recent Pat Inflamm Allergy Drug Discov 6: 121-129.

121.Zautner AE, Krause M, Stropahl G, Holtfreter S, Frickmann H, et al. (2010) Intracellular persisting Staphylococcus aureus is the major pathogen in recurrent tonsillitis. PLoS ONE 5: e9452.

122. Gould JM, Matz PS (2010) Otitis media. Ped Rev 31: 102-116.
This article was originally published in a special issue, Otitis Media handled by Editor(s). Dr. Seckin O Ulualp, University of Texas Southwestern Medical Center, USA
Submit your next manuscript and get advantages of OMICS Group submissions

\section{Unique features:}

- User friendly/feasible website-translation of your paper to 50 world's leading language

- Audio Version of published paper

Digital articles to share and explore

Special features:

200 Open Access Journals

15,000 editorial team

21 days rapid review process

Quality and quick editorial, review and publication processing

- Indexing at PubMed (partial), Scopus, DOAJ, EBSCO, Index Copernicus and Google Scholar etc

- Sharing Option: Social Networking Enabled

Authors, Reviewers and Editors rewarded with online Scientific Credits

- Better discount for your subsequent articles

Submit your manuscript at: www.omicsonline.org/submission/ 